\title{
Nuclear calcium signaling: a cell within a cell
}

\author{
M.A. Rodrigues ${ }^{1}$, D.A. Gomes², M.H. Nathanson ${ }^{3}$ and M.F. Leite ${ }^{1,4}$ \\ ${ }^{1}$ Departamento de Fisiologia e Biofísica, Universidade Federal de Minas Gerais, Belo Horizonte, MG, \\ Brasil \\ ${ }^{2}$ Faculdade de Ceilândia, Universidade de Brasília, Ceilândia, DF, Brasil \\ ${ }^{3}$ Departments of Medicine and Cell Biology, Yale University School of Medicine, New Haven, CT, USA \\ ${ }^{4}$ Howard Hughes Medical Institute, Chevy Chase, MD, USA
}

Correspondence to: M.F. Leite, Departamento de Fisiologia e Biofísica, UFMG, Av. Antônio Carlos, 6627, 31270-901 Belo Horizonte, MG, Brasil

Fax: +55-31-3409-2924. E-mail: leitemd@dedalus.Icc.ufmg.br

\begin{abstract}
Calcium $\left(\mathrm{Ca}^{2+}\right)$ is a versatile second messenger that regulates a wide range of cellular functions. Although it is not established how a single second messenger coordinates diverse effects within a cell, there is increasing evidence that the spatial patterns of $\mathrm{Ca}^{2+}$ signals may determine their specificity. $\mathrm{Ca}^{2+}$ signaling patterns can vary in different regions of the cell and $\mathrm{Ca}^{2+}$ signals in nuclear and cytoplasmic compartments have been reported to occur independently. No general paradigm has been established yet to explain whether, how, or when $\mathrm{Ca}^{2+}$ signals are initiated within the nucleus or their function. Here we highlight that receptor tyrosine kinases rapidly translocate to the nucleus. $\mathrm{Ca}^{2+}$ signals that are induced by growth factors result from phosphatidylinositol 4,5-bisphosphate hydrolysis and inositol 1,4,5-trisphosphate formation within the nucleus rather than within the cytoplasm. This novel signaling mechanism may be responsible for growth factor effects on cell proliferation.
\end{abstract}

Key words: Calcium; Proliferation; Receptor tyrosine kinases; Nucleus

Presented at the IV Miguel R. Covian Symposium, Ribeirão Preto, SP, Brazil, May 23-25, 2008.

Research supported by NIH (\#DK57751, \#DK34989, and \#DK45710), and by CNPq, FAPEMIG, and Howard Hughes Medical Institute.

Received July 3, 2008. Accepted September 29, 2008

\section{Introduction}

Intracellular $\mathrm{Ca}^{2+}$ can regulate cellular processes as distinct as cell death and proliferation (1). To achieve this versatility, there is increasing evidence that the spatial patterns of $\mathrm{Ca}^{2+}$ signals may determine their specificity (2). $\mathrm{Ca}^{2+}$ signals in nuclear and cytoplasmic compartments occur independently in several different cell types (3). However, the mechanisms and pathways that promote localized increases of free $\mathrm{Ca}^{2+}$ levels in the nucleus have not been entirely defined.

Recently, ligand-dependent translocation of receptor tyrosine kinases (RTKs) to the nucleus has been reported (4-7). RTKs can activate phospholipase C (PLC) that hydrolyzes phosphatidylinositol 4,5-bisphosphate $\left(\mathrm{PIP}_{2}\right)$, generating two intracellular products: inositol 1,4,5-tris- phosphate $\left(\operatorname{lns} \mathrm{P}_{3}\right)$, a universal $\mathrm{Ca}^{2+}$-mobilizing second messenger, and diacylglycerol, an activator of protein kinase $C$ (PKC) $(8,9)$. It has also been reported that the interior of the nucleus has all the $\mathrm{Ca}^{2+}$ signaling machinery necessary to produce nuclear $\mathrm{Ca}^{2+}$ signaling (10-15). The translocation of RTK to the nucleus indicates a new mechanism by which RTK increases $\mathrm{Ca}^{2+}$ in the nucleus and a new paradigm to explain the mechanism and pathways that promote nuclear $\mathrm{Ca}^{2+}$ signaling. This review highlights the recent advances in this area.

\section{The nucleus contains the machinery needed to locally increase $\mathrm{Ca}^{2+}$}

PLC hydrolyzes $\mathrm{PIP}_{2}$ to generate $\operatorname{InsP}_{3}(16)$, and $\operatorname{lns} \mathrm{P}_{3}$ then binds to the $\operatorname{Ins} \mathrm{P}_{3}$ receptor $\left(\operatorname{Ins} \mathrm{P}_{3} \mathrm{R}\right)$ to release $\mathrm{Ca}^{2+}$ 
from internal stores. It is well established that components necessary for Ins $\mathrm{P}_{3}$-mediated $\mathrm{Ca}^{2+}$ signaling are present in the plasma membrane and the endoplasmic reticulum, and there is evidence that these components are also present in the nuclear envelope as well. These components include PIP kinase (PIPK) $(17,18)$, which synthesizes $P_{I P}$, plus PLC (19) and the $\operatorname{lns}_{3} R(20-22)$. $\operatorname{lns}_{3} R$ is found on both the cytoplasmic and the intranuclear side of the nuclear membrane $(11,23)$, and the nuclear envelope contains sarco/endoplasmic reticulum $\mathrm{Ca}^{2+}$-ATPase (SERCA) pumps for $\mathrm{Ca}^{2+}$ reuptake as well (24). The nucleus, therefore, is equipped to produce $\operatorname{InsP}_{3}$ and to release and take up free $\mathrm{Ca}^{2+}$, independent of cytosolic $\operatorname{InsP}_{3}$ or $\mathrm{Ca}^{2+}$. Although $\mathrm{Ca}^{2+}$ can spread passively from the cytosol into the nucleus under certain circumstances (25-27), intranuclear $\mathrm{InsP}_{3}$ can increase $\mathrm{Ca}^{2+}$ directly within the nucleus as well, both in isolated nuclei $(12,20,28)$ and in nuclei within intact cells $(23,29,30)$. Moreover, RTKs may selectively activate nuclear isoforms of PLC $(18,31)$. However, until recently it was not known whether such receptors use this mechanism to increase $\mathrm{Ca}^{2+}$ in the nucleus. Two additional details about nuclear $\mathrm{Ca}^{2+}$ signaling have recently been established. First, the relative distribution of InsP ${ }_{3} \mathrm{R}$ isoforms in the nucleus and cytosol can differ among cell types (21). Because each $\operatorname{lns}_{3} R$ isoform has distinct sensitivities to $\operatorname{InsP}_{3}(32)$ and to $\mathrm{Ca}^{2+}(33,34)$, this differential distribution provides a mechanism by which the nucleus may be more sensitive than the cytosol to $\operatorname{lnsP}_{3}$ mediated $\mathrm{Ca}^{2+}$ release in certain cell types (21). Second, Ins $\mathrm{P}_{3}$-gated $\mathrm{Ca}^{2+}$ stores are found not only within the nuclear envelope, but also along a nucleoplasmic reticulum (23). PIPK and $\mathrm{PIP}_{2}$ are present in the interior of the

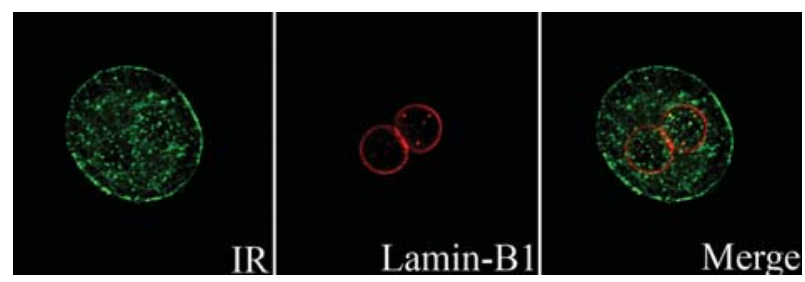

Figure 1. The insulin receptor translocates to the nucleus. Confocal immunofluorescence images of the insulin receptor (IR) after 5 -min stimulation with insulin $(10 \mathrm{nM})$. Isolated rat hepatocytes were double-labeled with a polyclonal antibody against insulin receptor $\mathrm{B}$ (BD Biosciences, USA) and a monoclonal antibody against the nuclear membrane marker Lamin-B1 (Abcam, USA) and then incubated with secondary antibodies conjugated to Alexa 488 and 555 (Invitrogen, USA), respectively. Images were collected with a Zeiss LSM 510 confocal microscope using a $63 \mathrm{X}, 1.4-\mathrm{NA}$ objective lens with excitation at 488 $\mathrm{nm}$ and observation at $505-550 \mathrm{~nm}$ to detect Alexa 488 (green), and excitation at $543 \mathrm{~nm}$ and observation at $560-610 \mathrm{~nm}$ to detect Alexa 555 (red). nucleus (14), and insulin and hepatocyte growth factor (HGF) can induce $\operatorname{InsP}_{3}$ production in nuclei $(6,7,35)$. These findings suggest that $\mathrm{Ca}^{2+}$ signaling machinery is present not only along the nuclear envelope but within the interior of the nucleus as well, which may provide an additional level of spatial control of nuclear $\mathrm{Ca}^{2+}$ signaling. In fact, $\mathrm{Ca}^{2+}$ signals induced by HGF and insulin begin in the nucleus $(6,7)$; nuclear $\mathrm{Ca}^{2+}$ signals are initiated in both SKHep-1 cells and primary hepatocytes when $\mathrm{PIP}_{2}$ is hydrolyzed to form $\operatorname{InsP}_{3}(6,7)$. Moreover, both the HGF receptor (c-met) and insulin receptor translocate to the nucleus (Figure 1). Translocation of the HGF receptor to the nucleus depends upon the adaptor protein Gab1, that contains a nuclear localization sequence and importin- $\beta 1$, and the formation of $\mathrm{Ca}^{2+}$ signals depends upon this translocation (6). Transport of proteins through the nuclear pore complex typically involves importins $\alpha / \beta$ and exportins. Specifically, importin- $\beta$ binds to the classical lysine-rich nuclear localization signal in the cargo, and importin- $\beta$ interacts with the importin- $\beta$ /cargo complex to guide it through the nuclear pore (6). Together, these data indicate that RTKs can activate the calcium signaling machinery within the nucleus.

\section{Increases in $\mathrm{Ca}^{2+}$ within the nucleus have specific cellular effects}

Nuclear $\mathrm{Ca}^{2+}$ signaling directly regulates cellular functions such as activation of kinases within the nucleus $(23,36)$, protein transport across the nuclear envelope $(11,37)$, and transcription of certain genes (38-40). For example, nuclear $\mathrm{Ca}^{2+}$ activates calmodulin kinase IV (36) and induces translocation of intranuclear but not cytosolic PKC (23). Gene transcription mediated by either the cAMP response element (CRE), CRE binding protein (CREB), or CREB binding protein (CBP) specifically depends upon increases in nuclear $\mathrm{Ca}^{2+}$, whereas gene transcription mediated by the serum response element instead is mediated by increases in cytoplasmic $\mathrm{Ca}^{2+}(38,39)$. Transcriptional activation of Elk-1 by epidermal growth factor also depends upon nuclear rather than cytosolic $\mathrm{Ca}^{2+}(40)$. Moreover, $\mathrm{Ca}^{2+}$ can bind to and directly regulate certain nuclear transcription factors (41), and can affect DNA structure as well (42). Nuclear $\mathrm{Ca}^{2+}$ can negatively regulate the activity of transcription factors as well (43). This was demonstrated by examining the relative effects of nuclear and cytosolic $\mathrm{Ca}^{2+}$ on the activity of the transcription enhancer factor TEF/TEAD. Chelation of nuclear but not cytosolic $\mathrm{Ca}^{2+}$ increased TEAD activity to twice that of controls, providing evidence that nuclear $\mathrm{Ca}^{2+}$ negatively regulates the activity of this transcription factor. Collec- 
tively, these findings show that nuclear $\mathrm{Ca}^{2+}$ regulates the expression of certain genes. Exogenous expression of the $\mathrm{Ca}^{2+}$ buffering protein parvalbumin has shown that intracellular $\mathrm{Ca}^{2+}$ regulates cell growth (44), but lack of effective experimental tools has made it difficult to demonstrate whether the effect of $\mathrm{Ca}^{2+}$ on cell growth is due to nuclear or cytosolic $\mathrm{Ca}^{2+}$ signals. Initial functional studies of nuclear $\mathrm{Ca}^{2+}$ on gene transcription relied on microinjection of $\mathrm{Ca}^{2+}$ chelators into either the nucleus or cytosol of individual cells (39), but it is impractical to use this laborintensive approach to conduct biochemical, cell population, or in vivo studies. However, a newer approach has been developed in which cells are infected with adenovirus to deliver $\mathrm{Ca}^{2+}$ chelators such as parvalbumin that are targeted to be expressed in either the nucleus or cytosol

\section{References}

1. Berridge MJ, Bootman MD, Lipp P. Calcium - a life and death signal. Nature 1998; 395: 645-648.

2. Berridge MJ, Bootman MD, Roderick HL. Calcium signalling: dynamics, homeostasis and remodelling. Nat Rev Mol Cell Biol 2003; 4: 517-529.

3. Bootman MD, Thomas D, Tovey SC, Berridge MJ, Lipp P. Nuclear calcium signalling. Cell Mol Life Sci 2000; 57: $371-$ 378.

4. Sardi SP, Murtie J, Koirala S, Patten BA, Corfas G. Presenilin-dependent ErbB4 nuclear signaling regulates the timing of astrogenesis in the developing brain. Cell 2006; 127: 185197.

5. Lo HW, Ali-Seyed M, Wu Y, Bartholomeusz G, Hsu SC, Hung MC. Nuclear-cytoplasmic transport of EGFR involves receptor endocytosis, importin beta1 and CRM1. J Cell Biochem 2006; 98: 1570-1583.

6. Gomes DA, Rodrigues MA, Leite MF, Gomez MV, Varnai P, Balla $T$, et al. c-Met must translocate to the nucleus to initiate calcium signals. J Biol Chem 2008; 283: 4344-4351.

7. Rodrigues MA, Gomes DA, Andrade VA, Leite MF, Nathanson $\mathrm{MH}$. Insulin induces calcium signals in the nucleus of rat hepatocytes. Hepatology 2008 (ahead of print).

8. Ponzetto C, Bardelli A, Zhen Z, Maina F, dalla Zonca P, Giordano $S$, et al. A multifunctional docking site mediates signaling and transformation by the hepatocyte growth factor/scatter factor receptor family. Cell 1994; 77: 261-271.

9. Eichhorn J, Kayali AG, Austin DA, Webster NJ. Insulin activates phospholipase C-gamma1 via a PI-3 kinase dependent mechanism in 3T3-L1 adipocytes. Biochem Biophys Res Commun 2001; 282: 615-620.

10. Irvine RF. Nuclear lipid signalling. Nat Rev Mol Cell Biol 2003; 4: 349-360.

11. Stehno-Bittel L, Luckhoff A, Clapham DE. Calcium release from the nucleus by InsP3 receptor channels. Neuron 1995; 14: 163-167.

12. Stehno-Bittel L, Perez-Terzic C, Clapham DE. Diffusion across the nuclear envelope inhibited by depletion of the
(45). Nuclear $\mathrm{Ca}^{2+}$ stimulates cell proliferation rather than apoptosis and specifically permits cells to advance through early prophase (45). Furthermore, nuclear $\mathrm{Ca}^{2+}$ regulates cell proliferation in multiple cell lines and in vivo (45).

\section{Conclusions and future directions}

The current evidence suggests that nucleoplasmic $\mathrm{Ca}^{2+}$ regulates cell cycle progression. RTKs move to the nucleus to generate $\operatorname{InsP}_{3}$ and therefore $\mathrm{Ca}^{2+}$ signals within the nucleus, and this nuclear $\mathrm{Ca}^{2+}$ signaling is important for cell proliferation. Further work is needed to identify the mechanism by which RTKs move to the nucleus and how nucleoplasmic $\mathrm{Ca}^{2+}$ control the pathways involved in cell cycle progression. nuclear $\mathrm{Ca}^{2+}$ store. Science 1995; 270: 1835-1838.

13. Malviya AN. The nuclear inositol 1,4,5-trisphosphate and inositol 1,3,4,5-tetrakisphosphate receptors. Cell Calcium 1994; 16: 301-313.

14. Boronenkov IV, Loijens JC, Umeda M, Anderson RA. Phosphoinositide signaling pathways in nuclei are associated with nuclear speckles containing pre-mRNA processing factors. Mol Biol Cell 1998; 9: 3547-3560.

15. Cocco L, Martelli AM, Vitale M, Falconi M, Barnabei O, Stewart GR, et al. Inositides in the nucleus: regulation of nuclear PI-PLCbeta1. Adv Enzyme Regul 2002; 42: 181193.

16. Berridge MJ, Lipp $P$, Bootman MD. The versatility and universality of calcium signalling. Nat Rev Mol Cell Biol2000; 1 : 11-21.

17. Cocco L, Gilmour RS, Ognibene A, Letcher AJ, Manzoli FA, Irvine RF. Synthesis of polyphosphoinositides in nuclei of Friend cells. Evidence for polyphosphoinositide metabolism inside the nucleus which changes with cell differentiation. Biochem J 1987; 248: 765-770.

18. Divecha N, Banfic H, Irvine RF. The polyphosphoinositide cycle exists in the nuclei of Swiss $3 T 3$ cells under the control of a receptor (for IGF-I) in the plasma membrane, and stimulation of the cycle increases nuclear diacylglycerol and apparently induces translocation of protein kinase $\mathrm{C}$ to the nucleus. EMBO J 1991; 10: 3207-3214.

19. Martelli AM, Gilmour RS, Bertagnolo V, Neri LM, Manzoli L, Cocco L. Nuclear localization and signalling activity of phosphoinositidase C beta in Swiss 3T3 cells. Nature 1992; 358: 242-245.

20. Malviya AN, Rogue P, Vincendon G. Stereospecific inositol 1,4,5-[32P]trisphosphate binding to isolated rat liver nuclei: evidence for inositol trisphosphate receptor-mediated calcium release from the nucleus. Proc Natl Acad Sci U S A 1990; 87: 9270-9274.

21. Leite MF, Thrower EC, Echevarria W, Koulen P, Hirata K, Bennett AM, et al. Nuclear and cytosolic calcium are regu- 
lated independently. Proc Natl Acad Sci U S A 2003; 100: 2975-2980.

22. Mak DO, Foskett JK. Single-channel inositol 1,4,5-trisphosphate receptor currents revealed by patch clamp of isolated Xenopus oocyte nuclei. J Biol Chem 1994; 269: 2937529378.

23. Echevarria W, Leite MF, Guerra MT, Zipfel WR, Nathanson $\mathrm{MH}$. Regulation of calcium signals in the nucleus by a nucleoplasmic reticulum. Nat Cell Biol 2003; 5: 440-446.

24. Rogue PJ, Humbert JP, Meyer A, Freyermuth S, Krady MM, Malviya AN. cAMP-dependent protein kinase phosphorylates and activates nuclear $\mathrm{Ca}^{2+}$-ATPase. Proc Natl Acad Sci U S A 1998; 95: 9178-9183.

25. Allbritton NL, Oancea E, Kuhn MA, Meyer T. Source of nuclear calcium signals. Proc Natl Acad Sci U S A 1994; 91: 12458-12462.

26. Fox JL, Burgstahler AD, Nathanson MH. Mechanism of long-range $\mathrm{Ca}^{2+}$ signalling in the nucleus of isolated rat hepatocytes. Biochem J 1997; 326 (Part 2): 491-495.

27. Lipp $P$, Thomas D, Berridge MJ, Bootman MD. Nuclear calcium signalling by individual cytoplasmic calcium puffs. EMBO J 1997; 16: 7166-7173.

28. Gerasimenko OV, Gerasimenko JV, Tepikin AV, Petersen $\mathrm{OH}$. ATP-dependent accumulation and inositol trisphosphate- or cyclic ADP-ribose-mediated release of $\mathrm{Ca}^{2+}$ from the nuclear envelope. Cell 1995; 80: 439-444.

29. Hennager DJ, Welsh MJ, DeLisle S. Changes in either cytosolic or nucleoplasmic inositol 1,4,5-trisphosphate levels can control nuclear $\mathrm{Ca}^{2+}$ concentration. $J$ Biol Chem 1995; 270: 4959-4962.

30. Santella L, Kyozuka K. Effects of 1-methyladenine on nuclear $\mathrm{Ca}^{2+}$ transients and meiosis resumption in starfish oocytes are mimicked by the nuclear injection of inositol 1,4,5-trisphosphate and cADP-ribose. Cell Calcium 1997; 22: $11-20$

31. Clark EA, Brugge JS. Integrins and signal transduction pathways: the road taken. Science 1995; 268: 233-239.

32. Newton CL, Mignery GA, Sudhof TC. Co-expression in vertebrate tissues and cell lines of multiple inositol 1,4,5-trisphosphate (InsP3) receptors with distinct affinities for InsP3. J Biol Chem 1994; 269: 28613-28619.

33. Hagar RE, Burgstahler AD, Nathanson MH, Ehrlich BE. Type III InsP3 receptor channel stays open in the presence of increased calcium. Nature 1998; 396: 81-84.

34. Ramos-Franco J, Fill M, Mignery GA. Isoform-specific function of single inositol 1,4,5-trisphosphate receptor channels. Biophys J 1998; 75: 834-839.

35. Martelli AM, Billi AM, Manzoli L, Faenza I, Aluigi M, Falconi $M$, et al. Insulin selectively stimulates nuclear phosphoinositide-specific phospholipase C (PI-PLC) beta1 activity through a mitogen-activated protein (MAP) kinase-dependent serine phosphorylation. FEBS Lett 2000; 486: 230-236.

36. Deisseroth K, Heist EK, Tsien RW. Translocation of calmodulin to the nucleus supports CREB phosphorylation in hippocampal neurons. Nature 1998; 392: 198-202.

37. Perez-Terzic C, Pyle J, Jaconi M, Stehno-Bittel L, Clapham DE. Conformational states of the nuclear pore complex induced by depletion of nuclear $\mathrm{Ca}^{2+}$ stores. Science 1996; 273: $1875-1877$.

38. Chawla S, Hardingham GE, Quinn DR, Bading H. CBP: a signal-regulated transcriptional coactivator controlled by nuclear calcium and CaM kinase IV. Science 1998; 281: 1505-1509.

39. Hardingham GE, Chawla S, Johnson CM, Bading H. Distinct functions of nuclear and cytoplasmic calcium in the control of gene expression. Nature 1997; 385: 260-265.

40. PusI T, Wu JJ, Zimmerman TL, Zhang L, Ehrlich BE, Berchtold MW, et al. Epidermal growth factor-mediated activation of the ETS domain transcription factor Elk-1 requires nuclear calcium. J Biol Chem 2002; 277: 27517-27527.

41. Carrion AM, Link WA, Ledo F, Mellstrom B, Naranjo JR. DREAM is a $\mathrm{Ca}^{2+}{ }^{+}$-regulated transcriptional repressor. $\mathrm{Na}$ ture 1999; 398: 80-84.

42. Dobi A, Agoston D. Submillimolar levels of calcium regulates DNA structure at the dinucleotide repeat (TG/AC)n. Proc Natl Acad Sci U S A 1998; 95: 5981-5986.

43. Thompson M, Andrade VA, Andrade SJ, PusI T, Ortega JM, Goes AM, et al. Inhibition of the TEF/TEAD transcription factor activity by nuclear calcium and distinct kinase pathways. Biochem Biophys Res Commun 2003; 301: 267-274.

44. Rasmussen CD, Means AR. The presence of parvalbumin in a nonmuscle cell line attenuates progression through mitosis. Mol Endocrinol 1989; 3: 588-596.

45. Rodrigues MA, Gomes DA, Leite MF, Grant W, Zhang L, Lam W, et al. Nucleoplasmic calcium is required for cell proliferation. J Biol Chem 2007; 282: 17061-17068. 